\title{
Protective Effects of Ginseng Coffee against Hydrogen Peroxide- induced Oxidative Damage in L6 Muscle Cells
}

\author{
Yeonmi Lee, Kyung-Tack Kim, Hye-Min Bae, Young-Chul Lee, and Sang Yoon Choi* \\ Korea Food Research Institute, Seongnam 463-746, Korea
}

This study investigated the antioxidant effects of ginseng coffee in L6 muscle cells. Ginseng coffee was prepared by coating and digesting coffee beans with ginseng concentrate. The ginseng coffee water extract potently protected against hydrogen peroxide-induced L6 cell death and adenosine triphosphate reduction in a dose-dependent manner; in fact, these cytoprotective effects were significantly greater than those of normal coffee. However, ginseng coffee did not exhibit significant radical scavenging or catalase-like activity. These results suggest that ginseng coffee might act as a cytoprotective agent in muscles, but that the protective effects are not due to a direct radical-reduction property but rather to another intracellular signaling factor.

Keywords: Ginseng, L6, Muscle cell, Antioxidant, Coffee

\section{INTRODUCTION}

Regular and proper exercise helps to prevent and alleviate hypertension, stroke, cardiovascular disease, diabetes, hyperlipidemia, and cancer [1,2]. However, strenuous exercise produces excessive reactive oxygen compounds, which cause oxidative damage to muscle tissues $[3,4]$. "Reactive oxygen" is a collective term for oxygen compounds such as the superoxide radical, hydroxyl radical, hydrogen peroxide $\left(\mathrm{H}_{2} \mathrm{O}_{2}\right)$, and singlet oxygen, which are generated during normal metabolic processes and perform several biological functions. However, excessively produced reactive oxygen compounds lead to tissue damage by lipid peroxidation and cause problems in DNA nucleic acid sequences $[5,6]$. The human body protects itself by producing antioxidant enzymes such as superoxide reductase, catalase, and glutathione peroxidase. However, the protective abilities of these enzymes differ greatly depending on a person's age and health. Vitamin $\mathrm{C}$ and $\beta$-carotene are known to assist in the antioxidant defensive system, and Choi et al. [7] reported that red ginseng reduced the serum malondialdehyde level, which is increased by reactive oxygen compounds generated during high-intensity aerobic exercise. In addition, a protective effect of maltol (2-methyl-3-hydroxy-4-pyrone) on oxygen radical-induced tissue damage was reported by Shin et al. [8].

Ginseng has been used not only as a traditional medicine, but also as a food; thus, it is manufactured as both health and general food products including extracts, pills, tablets, pouches, and red ginseng tea. In particular, ginseng has an "energy burst" effect in relation to athletic activity. This property has recently received increased interest in the United States, and several types of processed products with enhanced palatability, such as ginseng-laced beverages and ginseng coffee, are available on the market. As a part of such technology,

(c) This is an Open Access article distributed under the terms of the Creative Commons Attribution Non-Commercial License (http://creativecommons.org/licenses/by-nc/3.0/) which permits unrestricted non-commercial use, distribution, and reproduction in any medium, provided the original work is properly cited.

Received 13 Apr. 2010, Revised 20 Apr. 2010, Accepted 21 Apr. 2010

*Corresponding author

E-mail: sychoi@kfri.re.kr

Tel: +82-31-780-9307, Fax: +82-31-709-9876 
we developed and reported a Korean ginseng coffee with excellent palatability [9]. This study was conducted to investigate ginseng coffee's antioxidant effect on muscle cells compared to normal coffee. Its influence on cell viability and adenosine triphosphate (ATP) production was comparatively analyzed in $\mathrm{H}_{2} \mathrm{O}_{2}$-treated L6 muscle cells.

\section{MATERIALS AND METHODS}

\section{Experimental samples}

The ginseng-coated coffee beans used in this study were prepared according to the method described by Kim et al. [9]. Five grams per milliliter hydroxypropyl methyl cellulose was dissolved in distilled water, and white ginseng concentrate (Panax ginseng C.A. Meyer; Guan Industry Co., Seoul Korea) was added to each concentration of 5 degrees Brix $\left(5^{\circ} \mathrm{Bx}\right)$ and $20^{\circ} \mathrm{Bx}$ to make the coating solution. Coffee beans (Crystal Mountain, Cuba) were roasted at $250^{\circ} \mathrm{C}$ for 17 minutes, and the coating solution was sprayed onto the coffee beans (40 mL/100 g), which were then cooled. Ginseng-digested coffee beans were prepared by digesting $500 \mathrm{~g}$ of coffee beans (Crystal Mountain) in a $500 \mathrm{~mL}$ solution of white ginseng concentrate, diluted to each concentration of $5^{\circ} \mathrm{Bx}$ and $20^{\circ} \mathrm{Bx}$ for 4 hours, and then dried.

\section{Extraction}

Coffee beans, ginseng-digested coffee beans, and ginseng-coated coffee beans $\left(5^{\circ} \mathrm{Bx}, 20^{\circ} \mathrm{Bx}\right)$ were extracted using distilled water through a coffee machine (BCO 120T; DeLonghi, Bedford Heights, OH, USA) at $100^{\circ} \mathrm{C}$ for 5 minutes, whereupon the obtained extract was passed through filter paper and freeze-dried for experimental use as samples.

\section{Cell culture}

An L6 line of muscle cells was obtained from the Korean Cell Line Bank (Seoul, Korea) and incubated at $37^{\circ} \mathrm{C}$ in $5 \% \mathrm{CO}_{2}$ using Dulbecco's modified Eagle's medium (Gibco, Grand Island, NY, USA) containing $10 \%$ fetal bovine serum (Gibco) and 1\% antibiotic-antimycotic (Gibco).

\section{Cell viability measurement}

A measurement of cell viability was performed using an MTT [3-(4,5-dimethylthiazol-2-yl)-2,5-diphenyl-2Htetrazolium bromide] assay. To measure the protective effect of ginseng coffee on muscle cells, L6 cells were cultured for 24 hours by seeding them onto a 96-well plate at a concentration of $1 \times 10^{5}$ cells $/ \mathrm{mL}$ and treating them with each concentration of ginseng coffee extract and $1.5 \mathrm{mM} \mathrm{H}_{2} \mathrm{O}_{2}$ simultaneously. After culturing for an additional 24 hour, the cells were stained with MTT ( 0.5 $\mathrm{mg} / \mathrm{mL}$ in phosphate-buffered saline [PBS]) solution, and absorbance was measured at $540 \mathrm{~nm}$. The L6 protective effect of ginseng coffee extract was expressed as a percentage by calculating the recovery rate from the ginseng coffee extract treatment and the cell death rate from the blank treatment.

\section{ATP production measurement}

ATP production in L6 cells was measured using the ATP Bioluminescence Assay Kit HS II (Roche, Mannheim, Germany). L6 cells were cultured for 24 hours by seeding them onto a 96-well plate at a concentration of $1 \times 10^{5}$ cells $/ \mathrm{mL}$, treating them with each concentration of ginseng coffee extract and $1.5 \mathrm{mM} \mathrm{H}_{2} \mathrm{O}_{2}$ simultaneously, and culturing them for an additional 24 hour. The cells were then lysed for an ATP bioluminescence assay, and absorbance was measured with a luminometer (Molecular Devices, Sunnyvale, CA, USA).

\section{Catalase-like activity}

The catalase-like activity of ginseng coffee extract was measured using a catalase assay kit (Sigma-Aldrich, St Louis, MO, USA). Twenty-five microliters of 200 $\mathrm{mM} \mathrm{H} \mathrm{H}_{2} \mathrm{O}_{2}$ and $75 \mu \mathrm{L}$ of ginseng coffee extract dissolved in $50 \mathrm{mM}$ potassium phosphate buffer were mixed and then incubated at room temperature for 5 minutes, whereupon $900 \mu \mathrm{L}$ of $15 \mathrm{mM}$ sodium azide solution was added. Ten microliters of this reactant solution was mixed with $1 \mathrm{~mL}$ of $0.25 \mathrm{mM} 4$-aminoantipyrine and 2 $\mathrm{mM}$ 3,5-dichloro-2-hydroxybenzenesulfonic acid dissolved in a $150 \mathrm{mM}$ potassium phosphate buffer $(\mathrm{pH}$ 7.0), then incubated at room temperature for $15 \mathrm{~min}$ utes. The absorbance was measured at $520 \mathrm{~nm}$.

\section{DPPH radical scavenging activity}

Each $0.2 \mathrm{~mL}$ of ginseng coffee extract dissolved in $80 \%$ ethanol was added to $3 \mathrm{~mL}$ of ethanol, to which 0.8 $\mathrm{mL}$ of $4 \times 10^{-4} \mathrm{M}$ DPPH (2,2-diphenyl-1-picrylhydrazyl; Sigma-Aldrich) dissolved in ethanol was then added. This was vortexed for 10 seconds and left at room temperature for 10 minutes, and absorbance was measured at $517 \mathrm{~nm}[10,11]$. The DPPH radical scavenging activity was expressed as a percentage of the absorbance of the group to which DPPH was not added. Vitamin C was used as a positive control. 


\section{ABTS radical scavenging activity}

The ABTS [2,2'-azino-bis (3-ethylbenzthiazoline-6sulfonic acid)] radical scavenging activity of ginseng coffee extract was measured using a slight modification of the method proposed by van den Berg et al. [12]. To 0.1 M PBS (pH 7.4), $2.5 \mathrm{mM} \mathrm{ABTS}$, and $1.0 \mathrm{mM}$ AAPH [2,2'-azobis(2-methylpropionamidine) dihydrochloride] were added and left at $68^{\circ} \mathrm{C}$ for 12 minutes in a dark room, then quickly cooled to make an $\mathrm{ABTS}^{+}$solution. Each $20 \mu \mathrm{L}$ of ginseng coffee extract dissolved in PBS was added to $980 \mu \mathrm{L}$ of $\mathrm{ABTS}^{+}$solution and incubated at $37^{\circ} \mathrm{C}$ for 10 minutes, whereupon absorbance was measured at $734 \mathrm{~nm}$.

\section{Statistical analysis}

Each experimental result was expressed as the mean \pm SD. Statistical comparison between different treatments was calculated with ANOVA.

\section{RESULTS}

\section{L6 cell protective effect}

Strenuous exercise produces excessive reactive oxygen compounds, which cause oxidative damage to muscle tissues. The defensive effect of ginseng coffee against $\mathrm{H}_{2} \mathrm{O}_{2}$-induced oxidative damage was measured in L6 muscle cells to determine how ginseng coffee's protective effect compares to that of normal coffee. First, L6 cells were treated with 10 ppm of ginseng coffee extract for 24 hours, but no cell death was observed (Fig. 1), and 0.1, 1, and $10 \mathrm{ppm}$ ginseng coffee extracts were treated for 24 hours along with $1.5 \mathrm{mM} \mathrm{H}_{2} \mathrm{O}_{2}$. L6 cells treated only with $1.5 \mathrm{mM} \mathrm{H}_{2} \mathrm{O}_{2}$ showed a rate of cell death of $52.5 \%$, whereas those treated with $1.5 \mathrm{mM}$ $\mathrm{H}_{2} \mathrm{O}_{2}$ along with ginseng coffee extract demonstrated decreased cell death in a dose-dependent manner (Fig. 2 ). The rates of reduction of cell death in the $20^{\circ} \mathrm{Bx}$ ginseng-coated coffee extract were $13.5,32.8$, and $38.3 \%$ at $0.1,1$, and $10 \mathrm{ppm}$, respectively. Moreover, the ginseng coffee with a high concentration $\left(20^{\circ} \mathrm{Bx}\right)$ of ginseng displayed an excellent cell death inhibitory effect compared to ginseng coffee with a low ginseng concentration $\left(5^{\circ} \mathrm{Bx}\right)$. This was true for both the ginseng-coated and ginseng-digested coffee, suggesting no significant difference in the processing method of coating or digesting.

Also, the measurement of ATP production, which is the energy source for exercise and a critical requirement for cell survival, showed that the ginseng coffee treatment effectively inhibited the reduced ATP production

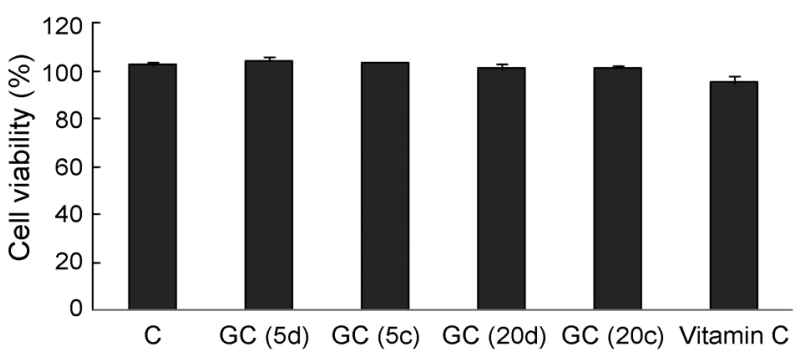

Fig. 1. Cell viabilities after treatment with ginseng coffee extract for 24 hours. L6 cells were treated with 10-ppm test samples. The data represent the mean $\pm S D$ of three experiments. C, normal coffee; CG (5d), 5 degrees Brix $\left(5^{\circ} \mathrm{Bx}\right)$ digested ginseng coffee; $\mathrm{CG}(5 \mathrm{C}), 5^{\circ} \mathrm{Bx}$ coated ginseng coffee; CG (20d), $20^{\circ} \mathrm{Bx}$ digested ginseng coffee; CG (20c), $20^{\circ} \mathrm{Bx}$ coated ginseng coffee.

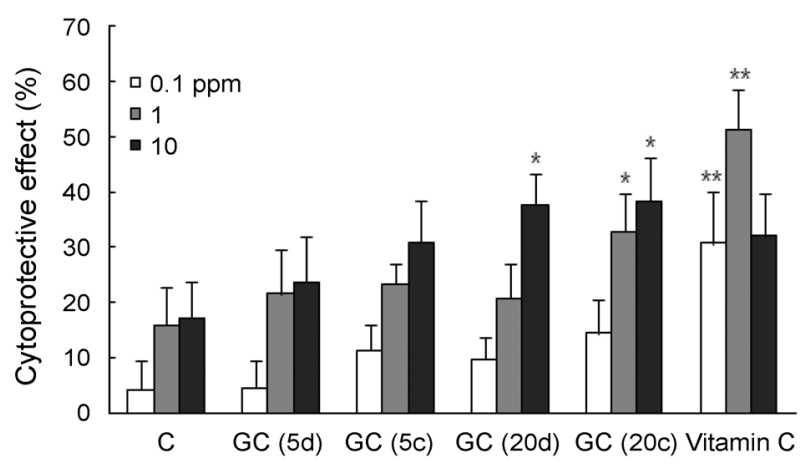

Fig. 2. Protective effect of ginseng coffee extract against $\mathrm{H}_{2} \mathrm{O}_{2}$-induced oxidative damage in L6 muscle cells. L6 cells were treated with $1.5 \mathrm{mM}$ $\mathrm{H}_{2} \mathrm{O}_{2}$ and test samples for 24 hour. The data represent the mean \pm SD of three experiments. Asterisks indicate significant differences compared to the control. C, normal coffee; CG (5d), 5 degrees Brix $\left(5^{\circ} \mathrm{Bx}\right)$ digested ginseng coffee; $C G(5 \mathrm{C}), 5^{\circ} \mathrm{Bx}$ coated ginseng coffee; $\mathrm{CG}(20 \mathrm{~d}), 20^{\circ} \mathrm{Bx}$ digested ginseng coffee; $C G(20 \mathrm{c}), 20^{\circ} \mathrm{Bx}$ coated ginseng coffee. ${ }^{*} p<0.05 ;^{* *} p<0.01$.

in $\mathrm{H}_{2} \mathrm{O}_{2}$-treated L6 cells compared to normal coffee (Fig. 3).

\section{Antioxidant enzyme-like activity}

Catalase is an important antioxidant enzyme that triggers the degradation of $\mathrm{H}_{2} \mathrm{O}_{2}$ into water and oxygen $[13,14]$. As shown in Fig. 4, the catalase-like activities of ginseng coffee and normal coffee extract were not observed at all concentrations, which indicates that ginseng coffee was unable to degrade $\mathrm{H}_{2} \mathrm{O}_{2}$ and thereby decrease its concentration. Therefore, the protective effect of ginseng coffee extract on the toxicity of $\mathrm{H}_{2} \mathrm{O}_{2}$ in L6 cells was confirmed to not involve a direct reduction of $\mathrm{H}_{2} \mathrm{O}_{2}$ concentration.

\section{Radical scavenging activity}

DPPH and ABTS assays were performed to determine whether ginseng coffee extracts can directly scavenge free radicals. Measurement of DPPH scav- 


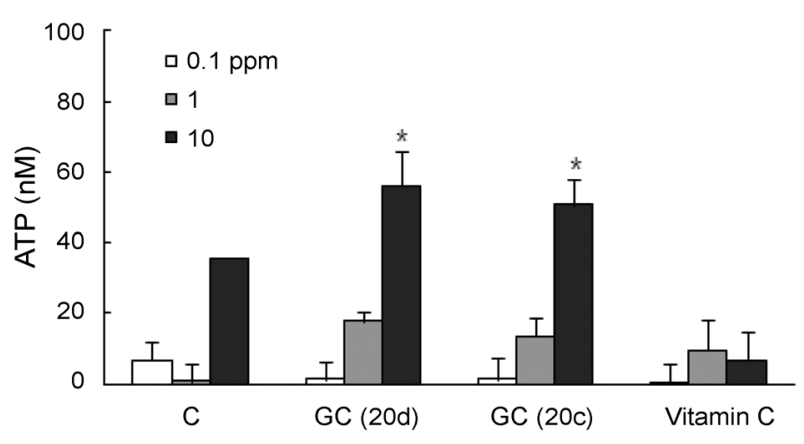

Fig. 3. Effects of ginseng coffee extracts on adenosine triphosphate (ATP) production in L6 muscle cells. L6 cells were treated with $1.5 \mathrm{mM}$ $\mathrm{H}_{2} \mathrm{O}_{2}$ and test samples for 24 hour. The data represent the mean $\pm \mathrm{SD}$ of three experiments. Asterisks indicate significant difference compared to the control. C, normal coffee; CG (20d), 20 degrees Brix $\left(20^{\circ} \mathrm{Bx}\right)$ digested ginseng coffee; $\mathrm{CG}(20 \mathrm{c}), 20^{\circ} \mathrm{Bx}$ coated ginseng coffee. ${ }^{*} p<0.05$.

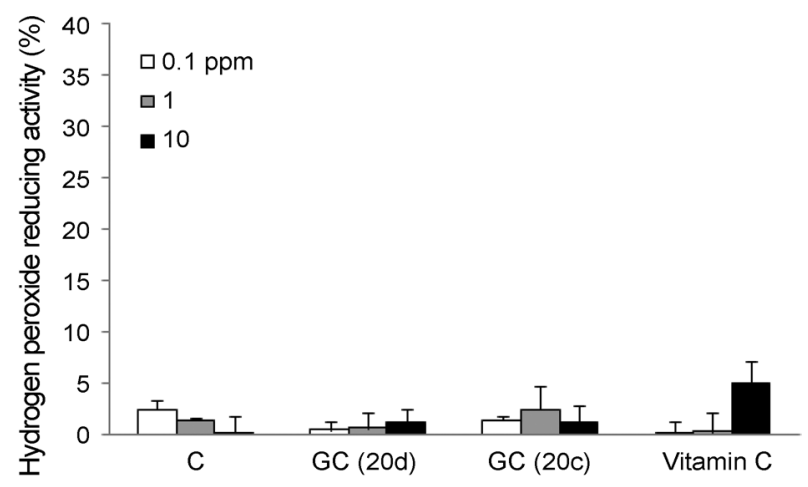

Fig. 4. Catalase-like activity of ginseng coffee extracts. The data represent the mean $\pm S D$ of three experiments. C, normal coffee; CG (20d), 20 degrees Brix $\left(20^{\circ} \mathrm{Bx}\right)$ digested ginseng coffee; $\mathrm{CG}(20 \mathrm{c}), 20^{\circ} \mathrm{Bx}$ coated ginseng coffee.

enging activity indicated no significant difference in the activity compared to normal coffee extract, and all the ginseng coffee extracts showed less than 20\% DPPH scavenging activity at $10 \mathrm{ppm}$ (Fig. 5). The ABTS scavenging activity of ginseng coffee extract at $10 \mathrm{ppm}$ was 51.0 to $66.1 \%$, which was slightly higher than the DPPH scavenging activity, but not significantly different at all concentrations compared to the scavenging activity of normal coffee extract (Fig. 6).

\section{DISCUSSION}

Ginseng coffee effectively suppressed L6 muscle cell death and reduced ATP production due to $\mathrm{H}_{2} \mathrm{O}_{2}$ compared to normal coffee. Thus, it is expected that the intake of ginseng coffee can effectively protect muscle cell damage due to increased reactive oxygen caused by strenuous exercise. However, no differences in DPPH and ABTS

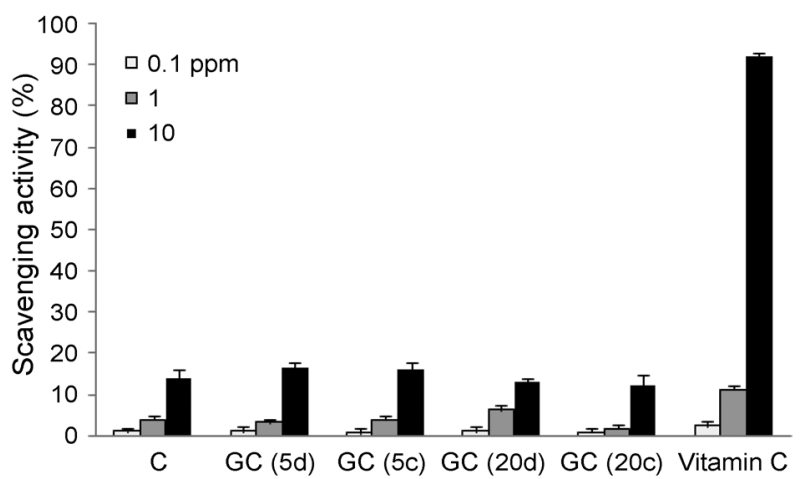

Fig. 5. DPPH radical scavenging activity of ginseng coffee extracts. The data represent the mean $\pm S D$ of three experiments. $C$, normal coffee; CG (5d), 5 degrees Brix $\left(5^{\circ} \mathrm{Bx}\right)$ digested ginseng coffee; $\mathrm{CG}(5 \mathrm{C}), 5^{\circ} \mathrm{Bx}$ coated ginseng coffee; $C G(20 \mathrm{~d}), 20^{\circ} \mathrm{Bx}$ digested ginseng coffee; $\mathrm{CG}(20 \mathrm{C}), 20^{\circ} \mathrm{Bx}$ coated ginseng coffee.

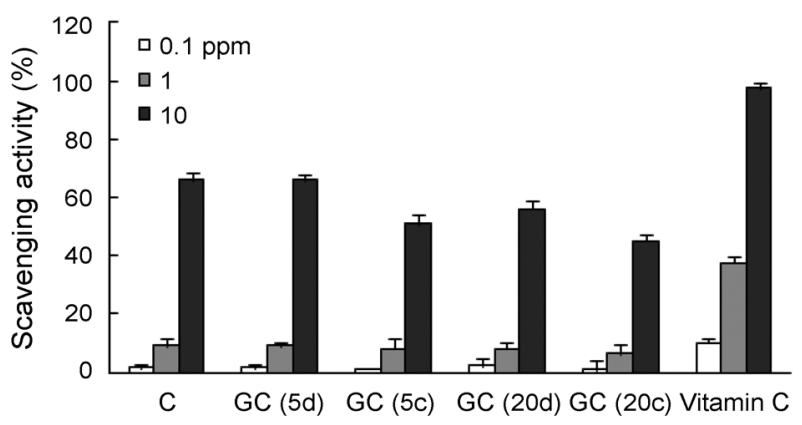

Fig. 6. ABTS radical scavenging activity of ginseng coffee extracts. The data represent the mean \pm SD of three experiments. $C$, normal coffee; $C G$ (5d), 5 degrees Brix $\left(5^{\circ} \mathrm{Bx}\right)$ digested ginseng coffee; $\mathrm{CG}(5 \mathrm{C}), 5^{\circ} \mathrm{Bx}$ coated ginseng coffee; $\mathrm{CG}(20 \mathrm{~d}), 20^{\circ} \mathrm{Bx}$ digested ginseng coffee; $\mathrm{CG}(20 \mathrm{c}), 20^{\circ} \mathrm{Bx}$ coated ginseng coffee.

radical scavenging activities or catalase-like activities were observed between ginseng coffee and normal coffee; therefore, the assumption was made that the muscle cell protective effect of ginseng coffee is caused not by the direct removal of free radicals, but by other effects on cell physiology and intracellular signaling.

\section{ACKNOWLEDGEMENTS}

This study was supported by a grant from the Korea Food Research Institute.

\section{REFERENCES}

1. Bassuk SS, Manson JE. Epidemiological evidence for the role of physical activity in reducing risk of type 2 diabetes and cardiovascular disease. J Appl Physiol 2005;99:11931204. 
2. Roberts CK, Barnard RJ. Effects of exercise and diet on chronic disease. J Appl Physiol 2005;98:3-30.

3. Hyun KY. An association of changed levels of inflammatory markers with hematological factors during one-time aerobic exercise in twenty-aged young men. J Life Sci 2009; 19:1658-1665.

4. Ji LL. Exercise, oxidative stress, and antioxidants. Am J Sports Med 1996;24:S20-S24.

5. Maughan RJ, Donnelly AE, Gleeson M, Whiting PH, Walker KA, Clough PJ. Delayed-onset muscle damage and lipid peroxidation in man after a downhill run. Muscle Nerve 1989;12:332-336.

6. Halliwell B. Reactive oxygen species and the central nervous system. J Neurochem 1992;59:1609-1623.

7. Choi J, Kim Y, Lee KM, Kim HJ. The effects of redginseng intaking on free radical produced during aerobic exercise in the elderly. J Ginseng Res 2004;28:27-32.

8. Shin JG, Park JW, Pyo JK, Kim MS, Chung MH. Protective effects of a ginseng component, maltol (2-methyl3-hydroxy-4-pyron) against tissue damages induced by oxygen radicals. Korean J Ginseng Sci 1990;14:187-190.

9. Kim KT, Lee YC, Cho CW, Rhee YK, Bae HM. Qual- ity characteristics of ginseng coffee treated by coating of white ginseng extract. J Ginseng Res 2010;34:1-7.

10. Kim SY, Gao JJ, Lee WC, Ryu KS, Lee KR, Kim YC. Antioxidative flavonoids from the leaves of Morus alba. Arch Pharm Res 1999;22:81-85.

11. Wang M, Jin Y, Ho CT. Evaluation of resveratrol derivatives as potential antioxidants and identification of a reaction product of resveratrol and 2, 2-diphenyl-1-picryhydrazyl radical. J Agric Food Chem 1999;47:3974-3977.

12. van den Berg R, Haenen GR, van den Berg H, Bast A. Applicability of an improved trolox equivalent antioxidant capacity (TEAC) assay for evaluation of antioxidant capacity measurements of mixtures. Food Chem 1999;66:511-517.

13. Bai J, Rodriguez AM, Melendez JA, Cederbaum AI. Overexpression of catalase in cytosolic or mitochondrial compartment protects HepG2 cells against oxidative injury. J Biol Chem 1999;274:26217-26224.

14. Tada-Oikawa S, Oikawa S, Kawanishi M, Yamada M, Kawanishi S. Generation of hydrogen peroxide precedes loss of mitochondrial membrane potential during DNA alkylation-induced apoptosis. FEBS Lett 1999;442:65-69. 